\title{
Distinctively Political Normativity in Political Realism: Unattractive or Redundant
}

\author{
Eva Erman $^{1}$ (D) - Niklas Möller ${ }^{1}$
}

Accepted: 29 March 2021 / Published online: 18 April 2021

(C) The Author(s) 2021

\begin{abstract}
Political realists' rejection of the so-called 'ethics first' approach of political moralists (mainstream liberals), has raised concerns about their own source of normativity. Some realists have responded to such concerns by theorizing a distinctively political normativity. According to this view, politics is seen as an autonomous, independent domain with its own evaluative standards. Therefore, it is in this source, rather than in some moral values 'outside' of this domain, that normative justification should be sought when theorizing justice, democracy, political legitimacy, and the like. For realists the question about a distinctively political normativity is important, because they take the fact that politics is a distinct affair to have severe consequences for both how to approach the subject matter as such and for which principles and values can be justified. Still, realists have had a hard time clarifying what this distinctively political normativity consists of and why, more precisely, it matters. The aim of this paper is to take some further steps in answering these questions. We argue that realists have the choice of committing themselves to one of two coherent notions of distinctively political normativity: one that is independent of moral values, where political normativity is taken to be a kind of instrumental normativity; another where the distinctness still retains a justificatory dependence on moral values. We argue that the former notion is unattractive since the costs of commitment will be too high (first claim), and that the latter notion is sound but redundant since no moralist would ever reject it (second claim). Furthermore, we end the paper by discussing what we see as the most fruitful way of approaching political and moral normativity in political theory.
\end{abstract}

Keywords Political realism · Political normativity $\cdot$ Instrumental normativity $\cdot$ Political moralism

In the debate between political moralism and political realism, realists have rejected the socalled 'ethics first' approach of political moralists (mainstream liberals), which has raised

Eva Erman

eva.erman@statsvet.su.se

Niklas Möller

niklas.moller@philosophy.su.se

1 Stockholm University, Stockholm, Sweden 
concerns about their own source of normativity (Erman and Möller 2015a, 2015b, 2018; Leader Maynard and Worsnip 2018). Some realists have responded to such concerns by moving from criticism to positive contributions (Hall 2017; Horton 2012; Rossi 2013; Sleat 2013, 2016a, 2016b, 2016c). Politics, they argue, is an autonomous, independent domain with its own evaluative standards (Rossi 2013: 559; Jubb and Rossi 2015a, 2015b). Therefore, it is in this source - rather than in some moral values 'outside' of this domain - that normative justification should be sought when theorizing justice, democracy, political legitimacy, and the like (Bellamy 2010; Galston 2010; Philp 2010; Sleat 2010). For realists the question about a distinctively political normativity is important, because they take the fact that politics is a distinct affair to have severe consequences for both how to approach the subject matter as such and for which principles and values can be justified. Since it is realists who insist on the reasonableness and usefulness of a distinctively political normativity, one would expect them to come up with a clear and reasonably supported answer. However, their characterizations have continued to be vague and unclear, and as convincingly argued by Jonathan Leader Maynard and Alex Worsnip, under at least five interpretations of what realists offer in terms of arguments for a distinctively political normativity, they all fail.

Hence, it is still far from clear what this distinctively political normativity consists of and why it matters. The aim of this paper is to take some further steps in answering these questions. We argue that realists have the choice of committing themselves to one of two coherent notions of distinctively political normativity: one that is independent of moral values, where political normativity is taken to be a kind of instrumental normativity; another where the distinctness still retains a justificatory dependence on moral values. We argue that the former notion is unattractive since the costs of commitment will be too high (first claim), and that the latter notion is sound but redundant since no moralist would ever reject it (second claim). Furthermore, we end the paper by discussing what we see as the most fruitful way of approaching political and moral normativity in political theory.

The first section below elucidates the vagueness that still prevails in recent writings with regard to what distinctively political normativity is and offers a conceptual framework for the analysis. Thereafter, we defend our first and second claims in the subsequent two sections. In the final section, we discuss a more productive way of approaching political and moral normativity.

\section{Vagueness in the Recent Debate and some Conceptual Clarifications}

Given the elusiveness of the idea of a distinctively political normativity in the realist literature, Leader Maynard and Worsnip (2018) do an admirable job in trying to make explicit some plausible suggestions of what realists might have in mind. In a reply to Leader Maynard and Worship, however, Robert Jubb complains that their claims are misconstrued by being 'philosophized' into a general and analytic form. His overall criticism is that it is a mistake to believe that disputes of what distinctively political normativity is can be solved "at the level of precise and perfectly generalizable methodological prescriptions" (Jubb 2019: 361). Instead, to get a true grasp of what realists mean by a distinctively political normativity, we must consider the concrete attempts that have been made by realists to describe, evaluate and offer guidance about politics (Jubb 2019: 362).

Jubb exemplifies with Judith Shklar's account of liberalism. Rather than focusing on a particular moral value or principle, Shklar starts out from the notion of cruelty and argues that 
this leads to what she calls 'liberalism of fear', which focuses on pathologies in the exercise of power (Shklar 1984, 1989). In a nutshell, liberalism's deepest grounding value is born out of the idea that "cruelty is an absolute evil" (Shklar 1989: 23). Conceptually, Shklar takes liberalism's aim to be to secure the political conditions necessary for the exercise of personal freedom. According to her own version of liberalism, "[e]very adult should be able to make as many effective decisions without fear or favor about as many aspects of her or his life as is compatible with the like freedom of every other adult" (Shklar 1989: 21). On this view, liberalism does not include any positive prescriptions about how people ought to conduct their lives; as a guide to political practices, it should refrain from offering ethical directives in general (Shklar 1989: 31). Instead, it is a response to certain undisputable actualities and therefore concentrates on damage control, restricting itself to proposals to restrain potential abusers of power (1989: 27, 31). In this sense, liberalism of fear is completely non-utopian (1989: 26).

It is easy see how this account of liberalism is attractive to realists. Not only is it nonutopian, it also seriously takes into account the constitutive features of politics, so often emphasized by realists as essential. As stressed by Jubb, "[t]aking seriously the reality of power in political relationships means thinking through its effects, both on those over whom it is exercised and on those who exercise it" (Jubb 2019: 366).

But how does Shklar's liberalism help us understand what realists mean by a distinctively political normativity? Jubb's thought seems to be that the key is the focus on 'cruelty' and 'fear of cruelty' (negative, existing) rather than on a utopian idea of full justice (positive, non-existing). But these notions do not offer any normative ammunition by themselves. Indeed, as pointed out by Shklar, while the fear of systematic cruelty is so universal that its prohibition has immediate appeal for everyone, liberalism cannot rest on "this or any other naturalistic fallacy" (Shklar 1989: 30). To become "a principle of political morality", she argues, liberalism of fear needs to be recognized as "a necessary condition of the dignity of persons" (1989: 30). And surely, however one defines the exact boundaries of the moral and political domains (more on this below), no one would reasonably claim that the dignity of persons in this context is a normative premise necessarily consistent with the constitutive features of politics or necessarily arising "from within politics" (Jubb 2019: 362; Williams 2005: 5). Similarly, from the conceptual claim that liberalism as a political doctrine aims to secure the political conditions necessary for the exercise of personal freedom, it does not follow that liberalism demands the "like freedom of every other adult" (our italics). To argue for the latter, Shklar is clearly relying on a notion of basic equality with no necessary connection to the constitutive features of politics. Hence, it is not clear to us why Shklar would be an illustration of the realist idea of a distinctively political normativity rather than an illustration of a non-utopian account of liberalism grounded in, among other things, moral values (the dignity of persons and basic equality).

Apart from arguing that we can get a grasp of what realists mean by distinctively political normativity through concrete examples, Jubb offers very little in the way of positive characterization of the distinctness claim. And what he does provide is very much a retreat from his previously strong claims about how politics is distinct from morality, now putting forward a much weaker claim (more on this below). Unfortunately, that retreat is not followed by any corresponding weakening on the side of the consequences of this distinctness for political theory. This is indeed problematic since these questions are intimately connected. Any interesting claim about distinctness ${ }^{1}$ has at least three aspects. There is a semantic aspect: its

\footnotetext{
${ }^{1}$ In previous writings, realists labelled this the priority question - whether or not morality was prior to politics.
} 
answer depends on what, more precisely, we mean by A being distinct from B. Then there is the question of evaluating whether $\mathrm{A}$ is in fact distinct from $\mathrm{B}$ in the specified sense. And lastly there is the question of how it all matters: what are the consequences if $\mathrm{A}$ and $\mathrm{B}$ are in fact thus distinct? If we give distinctness a very weak interpretation, then even if correct, it is unlikely to matter much, either methodologically or first-order normatively. That is why the realist oscillation between very strong and much weaker distinctness claims, while at the same time holding on to the same kind of radical idea about how it matters for political theory, is problematic.

The claim that kind A and kind B are distinct may mean different things. First we have a weak and strong semantic claim. In the weak form, that A and B are distinct may simply mean that there is a conceptual distinction to make between them, which in turn is typically interpreted in terms of different specifications for the terms marking out the two concepts. Now that is very week indeed, since "a polygon with three edges" and "a polygon with three lines" are conceptually different while still referring to the exact same shape-kind, i.e. the triangle. In a stronger form, it is typically assumed that there is not only a word-difference, but also a world-difference; more precisely, that the extensions of the two concepts are not identical (for all possible worlds): the descriptions may not refer to the same object or kind. ${ }^{2}$ Consequently, a quadrilateral, a rectangle and a square are all distinct kinds in this stronger sense, although both the rectangle and the square (and, trivially, the quadrilateral) are quadrilaterals.

When, in previous papers, we have endorsed claims such as that politics is distinct from morality or that political norms are distinct from moral norms, we are thinking of distinctness in this strong semantic way (Erman and Möller 2015a, 2015b, 2018). ${ }^{3}$ Whatever their relation beyond that, they are definitely distinct domains in this sense. However, much stronger claims than this have been made in this debate.

The typical distinctness claim in this debate seems to amount to a dichotomy claim. According to Rossi and Sleat, realists postulate a dichotomy between the realm of morality and the realm of politics, where the latter is said to require separate norms (Rossi and Sleat 2014: 691). Also the dichotomy claim can be interpreted in a weaker and a stronger sense. In the weaker form, if two kinds A and B form a dichotomy, something cannot at the same time be an A and a B. Rectangles and triangles are dichotomies in this weaker sense. In a stronger sense of dichotomy, A and B are dichotomies when (and only when), in addition to the previous condition, they together form a whole, so that any object either is an A or a B (but never both). An easy way to accomplish this is through negation: 'being a triangle' and 'not being a triangle' are dichotomies in this stronger sense.

As will be shown in our analysis below, the distinctness claims vary in the realist literature and so it seems to be an open question whether or not realism and moralism are in fact converse views. Our general stance is that the best way of analyzing any distinctness claim is

\footnotetext{
${ }^{2}$ This is sometimes expressed in terms of reduction: A is not reducible to B. But since reduction claims are often accused of being unclear as well, we stick to the possible world formulation here.

${ }^{3}$ Perhaps calling this strong form 'semantic' sounds misleading to some readers, since we are appealing not only to the sense but also the reference of a term. In our defence, we first point to the fact that some semantic theories (direct reference theories) appeal to the extension of a term for anchoring its meaning (see Putnam 1975 and Kripke 1980 for the general theory; and Boyd 1988 and Brink 1989, 2001 for an application to moral terms). More pragmatically, however, our purpose in the paper is to let our terminology help us mark a dividing line between the two weaker and relatively non-consequential interpretations of 'distinct', and the two much stronger ones. The (still) sensitive reader is of course welcome to exchange 'strong semantic' with any term they deem suitable.
} 
exactly to keep this an open question. Only after an interpretation is fixated and its reasonableness evaluated does it makes sense to assess whether it separates realist and moralist views, and what potential consequences for methodology and justification it may have.

\section{Distinctively Political Normativity as Unattractive}

In one of their arguments against a distinctively political normativity beyond the strong semantic reading, Leader Maynard and Worsnip point to the distinction between the evaluative and the normative. They acknowledge that political virtues are different from moral virtues, "if we construe 'political virtues' as including the broad skills that make someone an instrumentally effective political actor," such as "effectively get things done, persuade others, broker compromises, and generally advance their political agenda" (Leader Maynard and Worsnip 2018: 778). However, these virtues are not normative as such, they argue, but rather evaluative: they establish "features that make individuals good at a certain activity, but this does not (without supplementary normative claims) establish that they ought to engage in the activity" (Leader Maynard and Worsnip 2018: 779).

The basic thought that there is a difference between, say, being good at playing tennis and that playing tennis is good, is of course sound. But Leader Maynard and Worsnip's conclusion goes well beyond what is motivated by this distinction. While political virtues may be instrumentally effective, "our having reasons to perform instrumentally efficacious actions is parasitic on our having reasons to achieve the ends that these actions serve; instrumental normativity is primarily a matter of the transmission of reasons, so to speak, from ends to means rather than of the creation of reasons ex nihilo" (Leader Maynard and Worsnip 2018: 779). And while there are many normative demands on a political actor, such as upholding order, which necessitate the employment of nonmoral skills,

the enjoinment to employ those nonmoral skills is still a moral one, derivative on the moral demand to achieve the end. Without any such moral demand to achieve the end, there is no normative demand of any kind (save those of individual self-interest) to employ the nonmoral skills (Leader Maynard and Worsnip 2018: 779).

Now, there is nothing problematic as such to interpret instrumental normativity in terms of transmissions of reasons. In the chapter on instrumental reasons in the Oxford Handbook of Reasons and Normativity to which Leader Maynard and Worsnip refer, Niko Kolodny formulates instrumental normativity thusly in conditional terms:

If there is reason for one to pursue an end ... and if an action is in fact ... a means to that end ... then that is itself a reason for one to adopt the means (Kolodny 2018: 731-2).

As Kolodny explains in a footnote, this formulation is intentionally agnostic to what constitutes reasons for ends. That is a wise strategy when, as in Kolodny's case, the topic at hand is the nature of the relation between means and ends. In our present case, however, potentially different ways in which something may constitute a reason (and its many cousins, e.g. values and norms) is the main issue. Hence, it is unsatisfactory when, without further argument, Leader Maynard and Worsnip simply assume that such grounding reason can only be moral. 
In fact, one of the main candidates out there is the thought that being a means to an end is what constitutes being a reason. ${ }^{4}$ If completing the New York marathon is an end of Eve's, then she has a reason to put on her running shoes on a regular basis. Indeed, arguably the most common way of understanding the concept of instrumental normativity is in these end-relative terms.

$\mathrm{R}$ is an instrumental reason for $\mathrm{S}$ if (a) $\mathrm{S}$ has an end $\mathrm{M}$ and (b) $\mathrm{R}$ is a means to fulfil $\mathrm{M}^{5}$

In this way, instrumental reasons are understood as being constituted by desire-like attitudes of an individual: ends, goals, projects and the like. In a similar vein, and more in line with the collective enterprise of politics, we can talk about the ends and goals of a certain practice or role. ${ }^{6}$ Being a soldier, or a footballer, then implies that there are certain norms, values or virtues in place due to the ends or goals constitutive of soldiering or football. John Broome characterizes this notion of normativity thusly:

[I]n one sense 'normative' simply means to do with norms, rules or correctness. Any source of requirements is normative in this sense. For example, Catholicism is. Catholicism requires you to abstain from meat on Fridays. This is a rule, and it is incorrect according to Catholicism to eat meat on Fridays. So Catholicism is normative in this sense (Broome 2007: 162).

For instrumental norms in this sense, all we need is thus some sort of practice where the norms are determined by its ends, goals or other constraints. This interpretation opens up a possible reading of the distinctness claim: understanding political normativity as instrumental normativity (in this second sense), where the norms of politics are determined by the ends, goals and constraints of the activity. Being a political norm/value/reason/virtue then becomes a matter of whether or not the norm/value/reason/virtue is a proper means to the end(s) of politics.

It seems to us that many claims realists make fit nicely with this instrumental understanding of political normativity. Since the standards in the instrumental reading are given by the ends and constraints of the practice, it fits perfectly with one of the very defining features of political realism: that the political domain has its own norms and values, the sources of which can only be found within politics rather than on the 'outside' in some pre-political values (Bellamy 2010; Galston 2010; Philp 2010; Sleat 2010; Williams 2005). Moreover, not only are the relevant values found within rather than outside the political domain, politics is also a distinct sphere with its own evaluative standards (Rossi 2013: 559). As Sleat puts it, the realist aims to legitimate the political order from "justificatory resources that are internal to politics without reference to moral values" rather than from "normative values that are external to the political sphere and are taken to have antecedent authority over it," as is (allegedly) done by mainstream liberal theory (Sleat 2014: 317). Hence, no sources of normativity external to a political practice are needed for theorizing political principles (Jubb and Rossi 2015a).

\footnotetext{
${ }^{4}$ This is often called Humean Reasons (cf. Schroeder 2007 for an excellent overview).

${ }^{5}$ While this characterization is somewhat underspecified - much of the debate about instrumental rationality and normativity is about how exactly to specify the means-end relation (cf. Kolodny 2018; Kolodny and Brunero 2018 ) - it is precise enough for our present purposes.

${ }^{6}$ This is sometimes called 'institutional' reasons/normativity (e.g. Joyce 2011).
} 
This indicates that an instrumental reading is compatible with many realist descriptions of political values and norms in the abstract. Realist characterizations of how political norms and values are determined, however, also provide more positive indications of the instrumental reading which goes beyond mere compatibility. Here, both ends and constraints play a central role.

Realists' positive understanding of political values and norms typically refers to the end, goal or aim of politics. Indeed, Williams named the first political question "the securing of order, protection, safety, trust, and the conditions of cooperation;" it is "first because solving it is the condition of solving, indeed posing, any others" (Williams 2005: 3). A strong emphasis on order and stability as the end of politics runs like a common thread through realist writings (cf. Galston 2010, 408; Jubb 2015a: 921, 2016: 97; Sleat 2016c: 255). Moreover, political norms and values are taken to be justified through a number of key features of the political reality. These features, often referred to as the 'constitutive features' or 'general conditions' of politics (Sleat 2016a, 2016c, 2018), are said to include conditions such as deep disagreement and conflict of interest (Jubb 2015b: 679), coercion, authority, and the monopoly of organized violence (Jubb 2015a: 919; Sleat 2016c: 255). In addition, the necessity of power struggles is often taken to have normative import for political norms. As John Horton puts it, "gaining and maintaining political power are integral to politics in any circumstances" (Horton 2010: 435; see also Sleat 2013: 57). These aspects are necessary for politics, realists argue, and thus "ought to be taken as given or fixed points in any philosophy of politics" (Sleat 2016c: 254 $55)$.

In sum, realists' appeal to both the ends of politics and its necessary constraints, coupled with their insistence on politics having its own, independent source of normativity, together constitute a strong case for interpreting political normativity in instrumental terms. Political normativity then becomes comparable with other norms and values that are instrumental, such as those norms valid for the marathon runner to practice regularly, for the computer programmer to test her code to avoid errors, for the soldier to follow the order of her superiors, and for the bank employee to wear a tie at work. If we do not want to participate in these activities we can normally (but not always) ${ }^{7}$ opt out, and then these norms no longer have any force on us. But as long as we do participate, they have a grip.

By contrast, moral normativity is typically thought of as non-instrumental: moral norms apply to us in virtue of us being persons, and thus moral agents, and as such they are categorical (Kant 1785) and have an inescapable authority "that is absolute, not contingent upon any desire or preference or policy or choice" (Mackie 1977: 33). We cannot, as in the cases of the marathon runner or the bank clerk, escape the bindingness of moral norms in virtue of not running anymore or quitting our job. On this dominant conception, moral normativity is paradigmatically non-instrumental. ${ }^{8}$

\footnotetext{
${ }^{7}$ In the circumstances in which we find ourselves, it is not always feasible to opt out as we lose our desire to participate in a certain practice. While the marathon runner may arguably stop the exercise practice, it is difficult for the citizen to just opt out of the political practice.

${ }^{8}$ While being the overall dominating view in metaethics among moral realists (e.g. Smith 1994, c.f. also Miller 2013) and antirealists (e.g. Mackie 1977; Joyce 2001) alike, there are of course dissidents who argue that ultimately, moral norms depend on the ends of moral agents (e.g. Finlay 2014). Such ends, however, are typically taken to be very abstract, such as 'social cooperation', and as such, they become functionally equivalent to categorical reasons in the present context (with exceptions such as allowing the hermit to be unaffected by moral reasons binding for most of us). Indeed, were the ends taken to be more concrete and specific, they would run into the very arguments given against the instrumental construal of politics in the main text.
} 
Given the non-instrumental nature of morality, it seems that if political norms are thus instrumental, we have a good case not only to "posit a dichotomy between the realm of human action that is appropriately regulated by morality ... and the realm of politics, which requires separate norms" (Rossi and Sleat 2014: 692; our italics) but to actually justify "the politics/ ethics dichotomy" (Rossi and Sleat 2014: 692), thus moving well beyond the mere semantic distinctness granted by most - if not all - theorists. With the recurrent failure of realists to get any precise notion of distinctness off the ground, together with their continuous insistence that there is an important notion out there, it seems as if there is finally a straw to grasp: political normativity as instrumental normativity. Does that mean that the realist mission is accomplished?

Well, in the sense that we seem to have found a view that has profound consequences for how to justify political values and principles, it seems as if the answer is yes. If we have an instrumental reason to $\mathrm{X}$, the question of whether or not we morally speaking should $\mathrm{X}$ seems completely orthogonal. Consequently, in order to theorize political norms, looking elsewhere than on the aim(s) of the political domain and its constitutive constraints seems indeed to distort the question. Keeping an eye on the political ball seems here to entail not being distracted by moral norms and values, unless, of course, they are in line with the aims and constraints of politics. In this sense, acting morally in politics becomes analogous with acting morally in business on some infamous accounts: if acting morally is good for business, then the company should act morally. But if it is not, then there is no reason - indeed, even a counter-reason - to act in accordance with morality.

But as we mentioned in the beginning of the paper, there are at least three interrelated questions of importance here: the question of what we mean by 'distinct'; the question of whether politics is distinct from morality in this sense; and the question of what the consequences for political theory would be if the second question is answered in the affirmative. So just answering the first and last of these three will not do. The remaining pivotal question is whether political normativity should be viewed as instrumental. And we take there to be an overwhelmingly strong case for answering in the negative: political normativity as instrumental normativity is an unattractive option that fails to accommodate the essentially contestable nature of the boundary and content of politics.

Political norms (directly) and values (indirectly) aim to determine how we should regulate the political domain. This includes answering questions such as when the exercise of political power is legitimate, what constitutes a just society, and a myriad of related normative questions. It may include theorizing the scope of this domain, such as whether it contains the domestic society or whether we are talking about a global polity. And it may include questions of feasibility, implementation and operationalization. Each and any specification that is in any way substantial, however, is open to objections and alternative viewpoints. Politics is in this sense an essentially contested normative domain, both in terms of its boundaries and its content.

This has two consequences which speak against an instrumental interpretation of political normativity. First, it entails that any attempt to clearly demarcate a set of ends and constraints for the political domain lacks any 'trumping power' over alternative viewpoints. For practices regulated by instrumental norms, such as chess, it is perfectly valid to conclude that if someone moves the Rook diagonally, she is just not playing chess. However, you cannot in a similar manner dismiss an alternative account which says, for example, that the aim of politics is to find just rules for society constrained by nothing else than what lies in the realm of the empirically possible, on the grounds that it fails to be political because it goes against a 
definition of politics as "the sphere of contest between human wills competing for power or influence to determine what decision is taken" (Sleat 2013: 57). The boundaries of politics are essentially contested and thus, in contrast to instrumental normativity, all alternative conceptions are on pair, living and dying only in relation to the arguments that can be given for them rather than in relation to a pre-theoretically set boundary (see Erman and Möller 2018: 532 for an elaboration on this point).

Second, and even more importantly, just as the constraints of the political domain is essentially contested, so is the question of which kind of considerations speaks in favor of a set of political norms. In the game of Cheat, bluffing about the content of your cards is not only allowed but typically obligatory for having a change to win. Arguing that bluffing is not a valid Cheat-norm since truth-telling is morally obligatory simply has no force in the context of the game. In the context of politics, however, it is a disputed and open question when, and to what extent, a moral consideration has political force.

Indeed, non-instrumental ideas about the political subject, for example, as autonomous, free and equal, not only can, but virtually without exception do play a justificatory role in political norms. This is true not only on mainstream liberal accounts but also - in actual practice if not in the abstract - on the accounts of many, if not all, realists. With regard to political legitimacy, for example, realists typically argue for a number of conditions which clearly do not seem to be justified only by instrumental reasons, since some kinds of agreements are ruled out: in order for a political order to be legitimate, the agreement (Horton 2010) or willing consent (Bellamy 2010) must be perceived as free (Newey 2010), and thus cannot rely on means that are too tyrannical (Horton 2010), be coerced (Williams 2005) or be a result of total deception (Horton 2010). Indeed, some realists also appeal to basic human rights in the political sphere (Galston 2010).

In sum, we take a construal of political normativity as instrumental to come at an unacceptable cost, both internally - for realists - and for the theoretical debate as such. For realists, it would make them unable to justify the accounts they aim for. For the debate as such, realists would have to claim that competing accounts which use norms that cannot be reduced to instrumental norms in relation to (a particular understanding of) the ends and constraints of politics are simply changing the subject rather than doing normative political theory. ${ }^{9}$

\section{Distinctively Political Normativity as Redundant}

Realists oscillate between two positions in the literature, the first discussed above and the second discussed here. According to the first view, as we have seen, they claim to use normative sources solely in the political domain, being committed to "working within the parameters of a sphere of politics with its own normative standards" (Prinz and Rossi 2017: 352). Even if it is stressed that this does not entail that politics must be immoral or amoral, it means that "the appropriate standards of evaluation arise from within the political rather than from an external moral standpoint” (Williams 2005: 77; Sleat 2010). In other words, it need not "avoid morality altogether" (Jubb 2019: 362). This way of understanding moral evaluation as non-compulsory for normative political theory is common in the realist literature (Hall 2017; Williams 2005; Galston 2010; Jubb and Rossi 2015a, 2015b). However, on this view,

\footnotetext{
${ }^{9}$ Some realists have indeed attempted something very close to the latter argumentative strategy, e.g. Sleat $2016 \mathrm{c}$. See Erman and Möller 2018 for objections.
} 
Leader Maynard and Worsnip's reading of the realist view of distinctively political normativity as independent of moral normativity is not too demanding after all, as hinted by Jubb (2019: 364). Because being independent does not entail that political normativity necessarily is void of moral norms, only that it does not matter whether or not the political domain contains moral norms. As we have seen, this view is wholly in line with our instrumental account above and the dichotomy reading of distinctness.

According to the second view, to which realists often retreat when pressed on what exactly the distinctness of political normativity entails, moral norms and prescriptions are aligned with or filtered through politics as a category (Sleat 2016c), in case of which political normativity is distinct from moral normativity "in the sense that the weight, direction and relevance of different considerations would all systematically be altered by politics' constitutive features" (Jubb 2019: 362). Indeed, realists often point out that the political domain is distinct in that it involves special considerations that make political norms different from moral norms. On the level of norms, the argument goes, this is demonstrated by the divergence of moral and political wrongness. A central political norm, for example, is to respect the outcomes of a legitimate regulative process. And this is so even if the outcome as such happen to be morally wrong. Let us say, for example, that forbidding people to use a Burkini (a type of modesty swimsuit for women) on public beaches is morally wrong. Still, if its use is banned through a legislated political process, the regulation is politically legitimate. And since political rightness and moral wrongness may go apart, it is argued that political normativity is distinct from moral normativity. On the level of values or virtues, this is demonstrated by the different virtues needed for the different domains: political virtues may include the ability to compromise and even, as often stressed by realists, a certain ruthlessness, which may not be moral virtues.

Now, it is contested if, and to what extent, it is true that political and moral norms, values and virtues really differ. ${ }^{10}$ But even if everything in the above paragraph is granted, it does not demonstrate a move from a semantic reading of distinctness to a dichotomy reading, i.e., establishing that the political is not a moral kind. This is so because, on a closer inspection, the above-described tensions are evident within established moral domains as well. Within ordinary moral discourse, it is commonplace to argue in perfect analogue with the above regulation example that what is the morally right thing to do is distinct from the question of what one may force upon others (cf. Leader Maynard and Worsnip 2018: 766-7). Indeed, that is at the heart of the entire paternalism debate. ${ }^{11}$ But this example is just one instance of the fact that what we ought to do is generally context-dependent: that $\mathrm{S}$ ought to do $\mathrm{X}$ in circumstance $\mathrm{C}$ and that $\mathrm{S}$ ought to do $\mathrm{X}$ in circumstance $\mathrm{D}$ are two different questions. Thus, just as the fact that something is against another person's will may change what I should do to help her, the fact that something is decided through a democratic process may require of me to respect it even if it is in fact morally wrong. ${ }^{12}$

The problem with this second reading of distinctness, though, is that the realist view of political normativity becomes redundant, because few (if any) alleged moralists would deny this. Thus, realism would not contribute anything new with regard to sources of normativity in political theory. At the same time, given our criticism of the instrumental view above, this latter approach seems to be the only viable way forward. It fits well with the stronger semantic

\footnotetext{
${ }^{10}$ See Leader Maynard and Worsnip for skeptical points to this effect (2018: 777-81).

${ }^{11}$ For a classic, see for example Dworkin 1972.

${ }^{12}$ We write 'in fact' here to mark out that the issue here is not just what I happen to think is right, even if the latter in a trivial sense is what has motivational pull on me.
} 
view discussed earlier, according to which the extensions of two concepts are not identical (for all possible worlds). This is also in our view the most plausible way of understanding political normativity as distinct from moral normativity.

Interestingly, this is also the kind of political normativity underlying the work of non-ideal theorists, who theorize how different moral (and other) considerations are altered by the constitutive features of politics and the feasibility constraints tied to them. Yet, realists typically reject the idea that they join non-ideal theory in this endeavour. According to Rossi and Sleat, for example, the issue of feasibility is orthogonal to realism since realism's defining feature is "the attempt to give autonomy to political normativity" (Rossi and Sleat 2014: 690). And in Jubb's view, Laura Valentini's typology of ideal and non-ideal theory (Valentini 2012) is misleading since it mistakenly associates realists' complaint against moralism with Amartya Sen's complaint against so-called 'transcendental theory', which neglects that realists give a greater autonomy to distinctively political normativity than nonideal theorists (Jubb 2016: 394; Williams 2005: 3). At the same time, however, Jubb's summary of the guidelines that define political realism looks like 'business as usual' for any non-ideal theorist. According to his list, "a realist account of a political value must be based on an interpretation of the political situation in which the value is to be realized"; the interpretation of that situation must be plausible and avoid both "relentless despair and utopian hope"; the value that is theorized must be one that agents can expect to respect without being moral saints, and so on (Jubb 2017: 126). Arguably, these guidelines defining realism seem orthogonal to a distinctively political normativity according to which moral normativity is optional (dichotomy reading). Even if alleged moralists often conduct ideal theorizing, they do not reject non-ideal theory (quite the reverse).

\section{Sources of Normativity in Political Theory}

Against the backdrop of a strong semantic understanding of distinctively political normativity, let us end this paper by discussing what we see as the most fruitful way of approaching political and moral normativity in political theorizing. But first a few words about the distinction between moral and political normativity.

We suggest that the upshot of the many failed attempts to make any headway with the talk of a distinct political normativity which has any interesting consequences for political theory is that it is a dead-end. There is absolutely no benefit in trying to bend the existing, commonsensical characterizations of moral and political norms in order for it to do some argumentative work. Doing that would be to put the cart before the horse. Any merit that a notion of a distinct political normativity could have would piggyback on a satisfying, first-order argument for a set of political values and norms. And even then, attempting to recategorize the normative landscape to fit a particular normative account is problematic, due to the very objections given against the instrumental reading above (the lack of trumping power and the essentially contested question of which kind of considerations have political force).

We therefore propose that we may safely stick to the broad and commonsensical understanding of moral versus political norms. Something like this: political norms and values are simply the norms and values that regulate and structure the political domain; a paradigmatic example being the value of political liberty. And moral norms and values are the norms and values treated in moral philosophy proper (at the very least from Kant and onwards), paradigmatic examples being the equal respect for autonomous agency and that all individuals 
are free and equal. Thus understood, we argue below that moral values and norms have justificatory force in the political domain - i.e. for political normativity. ${ }^{13}$

As we saw in the previous section, in moral theory it is not typically considered morally right to force another person to act morally; yet, it seems reasonable within the moral domain that in some cases, we may (indeed, even be required to) do so. Let us say that Adam has a moral duty to give a certain percentage of his salary to Oxfam. Arguably, that does not give everybody (or even anybody) the right to force Adam to do so. Let us say further that Adam has a duty not to push Eve under a train. That arguably gives us a permission (and in some circumstances require of us) to stop Adam from doing so, even if by force. In a similar manner, is it not plausible that (paradigmatic) moral considerations might play a trumping role within the political domain? To return to the ban of the Burkini, are there any moral limits to what may be legitimately enforced? Whether or not this is the case in the political domain is controversial. But while it seems to us that the possibility that moral considerations play a trumping role within political normativity is sufficient to categorize political normativity as (also) moral normativity, it does not seem necessary. This is evident from comparison with paradigmatic sub-domains of morality such as, to name but a few, 'parental ethics', 'ethics of law', 'research ethics' or 'medical ethics'. In these areas, particular norms and values are specified and argued for. Typically, it is argued that certain roles within these domains, such as being a parent, judge of law, researcher or medical professional, include special duties or obligations that constrain what one ought to do qua parent or judge or researcher or medical professional. Consequently, it may be true that Andrea has done what she ought to do as a judge - e.g. convicted a citizen in line with the judicial law - although the law was morally unjust. Similarly, it might be a parental virtue to sometimes be biased towards one's own children even when moral norms tell otherwise.

Certainly, it is controversial whether or not, and to what extent, moral considerations may trump what the judge should do qua judge, and the parent qua parent. Maybe there are cases when what the judge or parent should do as persons, i.e. as moral agents, override what they should do as bearers of particular roles; cases when we simply must acknowledge that what $\mathrm{S}$ should do in $\mathrm{C}$ given role $\mathrm{X}$ is the same as what $\mathrm{S}$ should do in $\mathrm{C}$ regardless of whatever societal roles she occupies. Even so, rather than indicating that parental ethics or medical ethics are not moral domains, it indicates that they are moral domains with some given parameters which makes their 'brief' more limited since in order to assess what parental or medical virtues and norms are, we take into consideration the particular circumstances of parenthood and the medical profession. Conditioning the norms and virtues on these circumstances, they give us an opportunity to argue for more specific norms and virtues than in general morality.

Similarly, in the political domain, particular circumstances play a significant role in assessing the normative status of different instances of politics. For example, what we ought to do as citizens may differ from what we ought to do as individuals. Hence, it seems reasonable to us that an important source of normativity for a political theory is political normativity, which includes political norms and values that we understand as norms and values that regulate and structure the political domain. Typical political values include

\footnotetext{
${ }_{13}$ Then we may of course call them political norms and values, too. This is what Jubb and Rossi are getting at in Jubb and Rossi 2015a and 2015b. Doing so only further ensures that no interesting consequences follow for political theory, however, since then both realists and their supposed opponents agree, in substance if not in terminology (cf. Erman and Möller 2015b).
} 
'liberty', 'political obligation', 'equality before the law', 'consent of the governed', and so on, which primarily make sense in a legal-political context.

However, from this we should resist the realist inference that values that are not consistent with the general conditions of politics "cannot be in any meaningful sense values for the political domain" (Sleat 2016c: 260). If we return to Shklar's liberalism of fear, there is little to suggest that the values of the dignity of persons and basic equality would lose their normative force for political theory if it turned out that they were not consistent with the general conditions of politics. Quite the reverse, they could be used to criticize those conditions.

Apart from the source of political normativity, we argue that a defensible political theory must also utilize moral normativity. In other words, among those values that justify an account of, say, democracy, are also moral values. This does not entail that behind any value justifying democracy there must be a moral value. Only that at least some moral value plays a justificatory role among the grounding values. Consider, for example, the value of political equality, i.e., that citizens should have an equal say in the political decision-making. This seems to be a paradigmatic political value, being one of those values that typically regulate and structure the political domain. It is also commonly seen as the cornerstone of democracy. However, it seems strange to us to defend political equality without a notion of moral equality, e.g., in terms of the equal respect for persons. For it is not solely because we as citizens are equally subjected to the laws that we should have an equal say, but also because we are of equal moral worth as persons and therefore should be treated with equal respect. The same is the case with regard to (political) liberty vis-à-vis (non-political) freedom (see Hall 2017). It would not make sense to defend the former but rejecting the latter.

Hence, against realists, we argue that allowing the use of moral normativity and thus norms and values that are not necessarily consistent with the general conditions of politics is essential since without them, we have insufficient ammunition to criticize those conditions (since then only for example instrumental or epistemic reasons would apply). Indeed, in the search for the best answers to how we ought to organize our society and design our basic institutions, it might be the case that some of the general conditions of politics simply should be abandoned. They are contingent after all.

In their conclusion, Leader Maynard and Worship infer that political normativity has "ineliminable roots in morality" (2018: 787) and the conclusions drawn from political reasoning are "ultimately inherited from the underlying moral assumptions" (2018: 780). Wordings such as 'roots' and 'ultimately inherited' suggest that they take there to be an inevitable priority of moral values over political values, and a predetermined justificatory hierarchy between moral and political normativity. There is a more allowing reading available, though. On this reading, talk of 'roots' and 'inheritance' really just means that among the justificatory groundings of political norms, there must be some moral values and norms. To talk of 'inheritance' is then just to point out that political norms have moral genes in their DNA, so to speak (with 'ultimately' being just a slight overstep).

We think this ecumenical position is the one we ought to adopt. As we have argued in this section, moral values and norms are part of the justificatory grounding of any plausible normative political theory. But why insist on a justificatory hierarchy? At least methodologically or metatheoretically, it seems to be limiting the normative landscape.

The upshot of our view is a substantial leeway for the theorist. While both moral and political values are important for any defensible political theory, how they come into play in the justificatory process is dependent on several aspects that in our view should not be determined pre-theoretically, articulated in the form of metatheoretical or methodological restrictions. What goes under the umbrella term 'political theory' can have a myriad of 
different aims, contexts and limitations, and we contend that there are no general answers to be offered about the relationship between moral and political sources of normativity in the abstract from these many aims and contexts. The faithfulness to norms and values that are consistent with the general conditions of politics will depend on the aim of the theory and what its principles are supposed to regulate. For example, we may theorize a partial normative ideal of, say, democracy, rather than a comprehensive theory of, say, justice, in case of which the principles of the account will generate pro tanto rather than all-things-considered reasons for action and may be overridden by the more comprehensive account.

The aim of a theory also concerns what kind of principles are proposed, i.e. whether they are defended as higher-order principles that are meant to be realized (or approximated) within the remote future (or not at all) or more applied principles meant to be realized within the foreseeable future under current conditions, and so on. The appropriate feasibility considerations for each principle is dependent on what the principle is intended to regulate and achieve. And there are no predetermined limits to functional variety within an account and how many principles it may incorporate, as long as the principles harmonize so that they fit together: if an account includes an applied principle tied to demanding feasibility constraints and a more general higher-level principle tied to weaker or no feasibility constraints, the applied principle must be reasonable from the standpoint of the higher-level principle given the feasibility constraints assumed by the applied principle (and vice versa) (see Erman and Möller 2020). On this view, and in contrast to Leader Maynard and Worsnip on the stronger reading, defending a justificatory hierarchy between the parts of the account is not mandatory.

Acknowledgments The authors owe special thanks to Adrian Blau, Michael Frazer, Jonathan Leader Maynard and Enzo Rossi for comments on earlier drafts of this paper. Thanks also to the participants of the workshop "Political Normativity: Realism Meets Critics" held in Milan (October 2019) and to Carlo Burelli, Ilaria Cozzaglio, Chiara Destri and Greta Favara for organizing it. For valuable feedback we also thank the participants of the panel "Realism Verus Moralism and Related Dichotomies" at the ECPR Virtual General Conference (August 2020), and to its organizers, Michael Frazer and Sune Laegaard. In addition, we thank the editor and anonymous referees of Ethical Theory \& Moral Practice and are hugely grateful to the Swedish Research Council and to Marianne and Marcus Wallenberg Foundation for generously funding our research.

Funding Open access funding provided by Stockholm University.

Open Access This article is licensed under a Creative Commons Attribution 4.0 International License, which permits use, sharing, adaptation, distribution and reproduction in any medium or format, as long as you give appropriate credit to the original author(s) and the source, provide a link to the Creative Commons licence, and indicate if changes were made. The images or other third party material in this article are included in the article's Creative Commons licence, unless indicated otherwise in a credit line to the material. If material is not included in the article's Creative Commons licence and your intended use is not permitted by statutory regulation or exceeds the permitted use, you will need to obtain permission directly from the copyright holder. To view a copy of this licence, visit http://creativecommons.org/licenses/by/4.0/.

\section{References}

Bellamy R (2010) Dirty hands and clean gloves: Liberal ideals and real politics. Eur J Polit Theo 9:412-430 Boyd R (1988) How to be a moral realist. In: Sayre-McCord G (ed) Essays on moral realism. Cornell University Press, Ithaca, pp 187-228

Brink D (1989) Moral realism and the foundations of ethics. Cambridge University Press, Cambridge 
Brink D (2001) Realism, naturalism, and moral semantics. Soc Philos Policy 18:154-176

Dworkin G (1972) Paternalism. Monist 56:64-84

Erman E, Möller N (2015a) Political legitimacy in the real normative world: the priority of morality and the autonomy of the political. Br J Polit Sci 45(1):215-233

Erman E, Möller N (2015b) Why political realists should not be afraid of moral values. J Philos Res 40:459-464

Erman E, Möller N (2018) Where is political realism going? J Polit 80(2):525-538

Erman E, Möller N (2020) A world of possibilities: the place of feasibility in political theory. Res Publica 26:1-23

Finlay S (2014) Confusion of tongues: a theory of normative language. Oxford University Press, Oxford

Galston W (2010) Realism in political theory. Eur J Polit Theo 9:385-411

Hall E (2017) How to do realistic political theory (and why you might want to). Eur J Polit Theo 16:283-303

Horton J (2010) Realism, Liberal moralism and a political theory of modus vivendi. Eur J Polit Theo 9:431-448

Horton J (2012) Political legitimacy, justice and consent. Crit Rev Int Soc Pol Phil 15(2):129-148

Joyce R (2001) The myth of morality. Cambridge University Press, Cambridge

Joyce R (2011) The Error in 'The Error in the Error Theory'. Australas J Philos 89:519-534

Jubb R (2015a) Playing Kant at the court of king Arthur. Political Stud 63:919-934

Jubb R (2015b) The real value of equality. J Polit 77:679-691

Jubb R (2016) Norms, evaluations and ideal and non-ideal theory. Soc Philos Policy 33:393-412

Jubb R (2017) Realism. In A. Blau (ed) Methods in Analytical Political Theory. Cambridge University Press, pp. 112-130

Jubb R (2019) On what a distinctively political normativity is. Political Stud Rev 17:360-369

Jubb R, Rossi E (2015a) Political norms and moral values. J Philos Res 40:455-458

Jubb R, Rossi E (2015b) Why moralists should be afraid of political values: a rejoinder. J Philos Res 40:465-468

Kant I 1993[1785]. Grounding for the Metaphysics of Morals (trans J. W. Ellington). Indianapolis: Hackett publishing company

Kolodny N (2018) Instrumental reasons. In: Star D (ed) The Oxford handbook of reasons and normativity. Oxford University Press, Oxford, pp 731-763

Kolodny N, Brunero J (2018) Instrumental rationality. In E. N. Zalta (ed.) The Stanford Encyclopedia of Philosophy (Winter Edition)

Kripke S (1980) Naming and necessity. Basil Blackwell, Oxford

Leader Maynard J, Worsnip A (2018) Is there a distinctively political normativity? Ethics 128:756-787

Mackie JL (1977) Ethics: inventing right and wrong. Penguin, Harmondsworth

Miller A (2013) Contemporary Metaethics: an introduction. Polity Press, Cambridge

Newey G (2010) Two dogmas of liberalism. Eur J Polit Theo 9:449-465

Philp M (2010) What is to be done? Political theory and political realism. Eur J Polit Theo 9:466-484

Prinz J, Rossi E (2017) Political realism as ideology critique. Crit Rev Int Soc Pol Phil 20:348-365

Putnam H (1975). The meaning of 'meaning'. In Mind, Language and Reality: Philosophical Papers, vol. 2. Cambridge: Cambridge University press, pp. 215-271

Rossi E (2013) Consensus, compromise, justice and legitimacy. Crit Rev Int Soc Pol Phil 16(4):557-572

Rossi E, Sleat M (2014) Realism in normative political theory. Philos Compass 9:689-701

Schroeder M (2007) The Humean theory of reasons. In R. Shafer-Landau (ed.) Oxford Studies in Metaethics, vol.

2. Oxford University Press, pp. 195-219

Shklar J (1984) Ordinary vices. Harvard University Press, Cambridge

Shklar J (1989) The liberalism of fear. In: Rosenblum N (ed) Liberalism and the moral life. Harvard University Press, Cambridge, pp 21-38

Sleat M (2010) Bernard Williams and the possibility of a realist political theory. Eur J Polit Theo 9:485-503

Sleat M (2013) Liberal realism: a realist theory of Liberal politics. Manchester University Press, Manchester

Sleat M (2014) Legitimacy in realist thought: between moralism and realpolitik. Political Theory 42(3):314-337

Sleat M (2016a) Realism, liberalism and non-ideal theory; or, are there two ways to do realistic political theory? Political Stud 64(1):27-41

Sleat M (2016b) The value of global justice: realism and moralism. J Int Political Theory 12(2):169-184

Sleat M (2016c) What is a political value? Political philosophy and Fidelity to reality. Soc Philos Policy 33:252-272

Sleat M (2018) Introduction. In: Sleat M (ed) Politics recovered: realist thought in theory and practice. Columbia University Press, New York, pp 1-26

Smith M (1994) The moral problem. Oxford University Press, Oxford

Valentini L (2012) Ideal vs. non-ideal theory: a conceptual map. Philos Compass 7(9):654-664

Williams B (2005) In the Beginning Was the Deed (ed. G. Hawthorn). Princeton, NJ: Princeton University press

Publisher's Note Springer Nature remains neutral with regard to jurisdictional claims in published maps and institutional affiliations. 